\title{
Keeping Sense Open: Jean-Luc Nancy, Karl Rahner, and Bodies
}

\author{
PETER JOSEPH FRITZ \\ College of the Holy Cross
}

This article introduces the French philosopher Jean-Luc Nancy to theologians by placing him in critical dialogue with Karl Rahner. It examines how Nancy's deconstruction of Christianity accuses Western reason, including Christianity, of forgetting the body and supporting an ethos of disembodiment. Nancy proposes a new opening of reason (déclosion, "dis-closure") and a corresponding praxis ("adoration"). This reason and praxis involve an exit from Christianity. Rahnerian essays on matter, spirit, and sacramentality demonstrate that while Christianity has, historically, fallen prey to the pathologies Nancy identifies, it also has thought in terms of something like dis-closed reason and has practiced something like "adoration." While Nancy's insistence on the need for an exit from Christianity is not necessarily well posed, his deconstruction of Christianity can help Christian theologians as they develop thinking that supports an ethos sensitive to the body-or that keeps the body's sense open.

Keywords: body, Eucharist, deconstruction, Jean-Luc Nancy, postmodern theology, Karl Rahner, symbol

MONG the postmodern provocateurs Catholic theology must address is
a French philosopher who remains relatively unfamiliar to English-
speaking theologians: Jean-Luc Nancy (1940-). His influence is
growing, so his thought bears consideration. ${ }^{1}$ This article grapples with his

${ }^{1}$ Nancy's ongoing project has garnered great scholarly interest. The first and most potent manifestation of this is Fordham University Press's massive effort to translate and to publish Nancy's works. At this point, its catalogue includes around twenty-and counting-of Nancy's works, including the main ones on Christianity. The foremost secondary

Peter Joseph Fritz (PhD, Notre Dame) teaches Christian theology, history, and aesthetics in the Department of Religious Studies at the College of the Holy Cross. He has authored Karl Rahner's Theological Aesthetics (Washington, DC: The Catholic University of America Press, 2014) and articles in Theological Studies, Philosophy \& Theology, Heythrop Journal, Modern Theology, Irish Theological Quarterly, and Political Theology. 
most recent and most significant project, which he calls a deconstruction of Christianity. This deconstruction aims to lay bare Christianity's limits and latent possibilities. ${ }^{2}$ Nancy interrogates Christian thinking and practices related to the "body of God," which symbolizes the limits and possibilities not just of Christianity, but also of Western traditions (philosophical, cultural, economic) more generally. ${ }^{3}$ His project begins with the words of Eucharistic consecration (Hoc est enim corpus meum), proceeds through the heart of Christian theology (Christology), and proposes a praxis for an age after Christianity's self-exhaustion ("adoration"). ${ }^{4}$ His endeavor is provocatively posed, and invites theological engagement.

I propose in this article to do two related things: (1) to introduce Nancy to a theological audience by placing him in critical dialogue with Karl Rahner, and (2) in performing the first operation, to continue the conversation between Rahner's theology and postmodern philosophy, which others began and with which I have been intensively engaged over the past

source in English is a volume of essays also published by Fordham: Alena Alexandrova, Ignaas Devisch, Laurens Ten Kate, and Aukje Van Rooden, eds., Re-treating Religion: Deconstructing Christianity with Jean-Luc Nancy (New York: Fordham University Press, 2012). But there are others, of which I cite just some, one may consult for further bibliography: Benjamin C. Hutchens, Jean-Luc Nancy and the Future of Philosophy (Montreal: McGill-Queen's University Press, 2005), 85-102; Joeri Schrijvers, "What Comes after Christianity? Jean-Luc Nancy's Deconstruction of Christianity," Research in Phenomenology 39 (2009): 266-91; Christopher Watkin, Difficult Atheism: PostTheological Thinking in Alain Badiou, Jean-Luc Nancy, and Quentin Meillassoux (Edinburgh: Edinburgh University Press, 2011); Alfonso Cariolato, "Jean-Luc Nancy and the Deconstruction of Faith," in Jean-Luc Nancy and Plural Thinking: Expositions of World, Ontology, Politics, and Sense, ed. Peter Gratton and Marie-Eve Morin (Albany: State University of New York Press, 2012), 27-42; Marie-Eve Morin, Jean-Luc Nancy (Cambridge: Polity Press, 2012), 48-71; Mayra Rivera, Poetics of the Flesh (Durham, NC: Duke University Press, 2015), 96-101.

${ }^{2}$ My formulation simplifies somewhat Nancy's description of deconstruction, which he discusses in terms of the "points of assemblage" of Christianity where "there is perhaps something to be brought to light and let play as such, something that Christianity may not yet have freed." Thus deconstruction aims to discover how Christianity is put together so that, perhaps, it might find different possibilities for its construction. Jean-Luc Nancy, Dis-Enclosure: The Deconstruction of Christianity, trans. Bettina Bergo, Gabriel Malenfant, and Michael B. Smith (New York: Fordham University Press, 2008), 149.

3 Jean-Luc Nancy, Corpus, trans. Richard Rand (New York: Fordham University Press, 2008), 73 .

4 Nancy, Corpus, 3; Nancy, Dis-Enclosure, 151; Jean-Luc Nancy, Adoration: The Deconstruction of Christianity II, trans. John McKeane (New York: Fordham University Press, 2012), 13. 
several years. ${ }^{5}$ Rahner the faithful Jesuit priest and Nancy the dogged atheist (or postatheist) may seem strange conversation partners. But the conversation makes sense once one recognizes that these thinkers are analogously indebted to Martin Heidegger. From Heidegger, Rahner and Nancy learn two important things relevant to my argument. First, they learn from Heidegger to diagnose the Western tradition (philosophical and Christian) as a history of forgetting. For Heidegger, the Western philosophical tradition (including Christianity) is a history of the forgetting of being. ${ }^{6}$ For Rahner, modern Catholic tradition has forgotten numerous truths that need remembering. ${ }^{7}$ For Nancy, Western philosophy and Christian theology have forgotten bodies along their way to philosophical and theological certitude. ${ }^{8}$ Second, from Heidegger, both Rahner and Nancy learn to be thinkers of "ethos." Heidegger most famously uses the word "ethos" in the "Letter on Humanism" (1946), where he defines it as "the open region in which man dwells." ${ }^{9}$ William McNeill's study on ethos in Heidegger shows how the term ties together his key themes and texts, with ethos being understood broadly as a "way of being." ${ }^{10}$ Rahner's encounter with Heidegger led to

5 Andrew Tallon, "Editor's Introduction," in Karl Rahner, Hearer of the Word: Laying the Foundation for a Philosophy of Religion, trans. Joseph Donceel, ed., with an introduction, Andrew Tallon (New York: Continuum, 1994), ix-xxii; Michael Purcell, Mystery and Method: The Other in Rahner and Levinas (Milwaukee: Marquette University Press, 1998); Purcell, "Rahner amid Modernity and Post-Modernity," in The Cambridge Companion to Karl Rahner, ed. Declan Marmion and Mary Hines (New York: Cambridge University Press, 2005), 195-210; Ethna Regan, "Not Merely the Cognitive Subject: Rahner's Theological Anthropology," in Karl Rahner: Theologian for the Twenty-First Century, ed. Pádraic Conway and Fáinche Ryan (Bern: Peter Lang, 2010), 121-40; Peter Joseph Fritz, Karl Rahner's Theological Aesthetics (Washington, DC: Catholic University of America Press, 2014); Fritz, "Karl Rahner Repeated in Jean-Luc Marion?," Theological Studies 73, no. 2 (2012): 318-38; Fritz, "Karl Rahner, Friedrich Schelling, and Original Plural Unity," Theological Studies 75, no. 2 (2014): 284-307.

${ }^{6}$ Martin Heidegger, Being and Time, trans. John Macquarrie and Edward Robinson (San Francisco: HarperSanFrancisco, 1962), \$1 and \$44b; and Heidegger, Introduction to Metaphysics, trans. Gregory Fried and Richard Polt (New Haven, CT: Yale University Press, 2000), 20.

7 This is true of a broad swath of Rahner's writings on God, mystery, symbol, church, Mary, concupiscence, and various other topics, but clearest for our purposes here is Karl Rahner, "Forgotten Truths about the Sacrament of Penance," in Man in the Church, vol. 2 of Theological Investigations, trans. Karl H. Kruger (Baltimore: Helicon Press, 1963), 135-74.

${ }^{8}$ This is much of the upshot of Corpus.

9 Martin Heidegger, "Letter on Humanism," in Basic Writings, ed. David Farrell Krell (New York: HarperCollins, 2008), 256.

${ }^{10}$ William McNeill, The Time of Life: Heidegger and Ethos (Albany: State University of New York Press, 2006). 
what I consider Rahner's chief theological achievement: presenting the breadth and wholeness of the Catholic ethos, or way of being. ${ }^{11}$ Jean-Luc Nancy, too, is exercised by the question of ethos. In an essay that invokes Heidegger's reference to ethos in the "Letter on Humanism," Nancy defines ethos as "protect[ing] sense from being filled, as well as from being emptied." 12 We shall see below the importance of "sense" for Nancy, but for now suffice it to say that ethos plays the central role in his thinking: keeping sense open.

Rahner and Nancy belong together as thinkers of forgotten truths and of ethos. In this article I treat their concerns with recovering truths about the body and materiality, and with describing an ethos that follows from such recovery. Nancy contends that Christianity has been complicit in covering over the body with signs, in demanding that bodies themselves be signs of principles or spirits, and thus in obscuring truth (figured as the "coming of sense"). He understands "sense" in all its connotations, with privilege given to embodied experiences of sensation. He appeals for a mode of thinking and living that is open to the body and resists the closure of sense. Nancy's appeal for the opening of sense bears striking similarities to Rahner's theology of materiality, where he aims to recover the body from the tendency in earlier models of Christian theology to see materiality as profane or of worth only inasmuch as it relates to spirit. I argue that Nancy's deconstruction of Christianity and Rahner's theology can be mutually illuminating; Rahner can help to introduce theologians to Nancy, and Nancy can help us to hear once more Rahner's call for greater theological attention to material and embodied life. Furthermore, Nancy's and Rahner's dual appeals for keeping sense open can impel Christian theologians to reflect more deeply on the Christian ethos.

I begin with a brief exposition of Nancy's deconstruction of Christianity, setting it within his wider concern with "sense." Then two sections expose the two movements of Nancy's deconstruction of Christianity, la déclosion and "adoration"; they show how Nancy proposes to open Western reason beyond its forgetting of bodies and to advocate a form of life that comports with the sense of bodies. The two following sections detect resonances between the two movements of Nancy's deconstruction of Christianity and Rahner's mid-twentieth-century reevaluation of Catholic theology. The sections' particular foci are, respectively, Rahner's theology of materiality and his "Copernican turn" in sacramental theology and life. ${ }^{13}$ The concluding

11 Fritz, Karl Rahner's Theologial Aesthetics, 11-12.

12 Nancy, Dis-Enclosure, 122.

13 The main texts under consideration are the following: Karl Rahner, "The Unity of Spirit and Matter in the Christian Understanding of Faith," in Concerning Vatican Council II, 
section points out the irony that Nancy's logic tends to disembody Christianity. More appreciatively, it suggests that Nancy's pleas for remembering the body resonate with central points of Rahner's theology, and could lead to a fascinating theology of sense that would take into account Nancean critiques while retaining the materiality of Christianity's history.

\section{Nancy's Deconstruction of Christianity}

Thus far Nancy's deconstruction of Christianity spans three slim yet exceedingly difficult volumes. Corpus (1992) is a prologue. La déclosion (2005) officially opens the project. L'adoration (2010) continues it. ${ }^{14}$ Other books, like La creation du monde, ou la mondialisation (2002), Au fond des images (2003), and Noli me tangere: Essai sur la levée du corps (2003), along with a series of essays that have been gathered and translated into English as Corpus II: Writings on Sexuality (2013), aid the project under other auspices. ${ }^{15}$ This philosophical intervention, then, is becoming sizable.

While many notable European intellectuals have begun to turn from strict atheism to a positive, if halting, estimation of religion, Nancy resists this impulse. ${ }^{16} \mathrm{He}$ supports maintaining atheism in the face of the contemporary return to religion. In fact, Nancy will reject even atheism as too residually

vol. 6 of Theological Investigations, trans. Karl H. Kruger and Boniface Kruger (Baltimore: Helicon Press, 1969), 153-77; Rahner, "Überlegungen zum personalen Vollzug des sakramentalen Geschehens," in Leiblichkeit der Gnade: Schriften zur Sakramentenlehre, vol. 18 of Sämtliche Werke, ed. Wendelin Knoch and Tobias Trappe (Freiburg: Herder, 2003), 458-76; Rahner, "Considerations on the Active Role of the Person in the Sacramental Event," in Theology, Anthropology, Christology, vol. 14 of Theological Investigations, trans. David Bourke (New York: Seabury Press, 1976), 161-84. Since there are problems with the Bourke translation that necessitate retranslation, I shall cite the German, giving my translations.

${ }^{14}$ Jean-Luc Nancy, Corpus (Paris: Diffusion Seuil, 1992); Nancy, Déconstruction du christianisme, vol. 1, La déclosion (Paris: Galilée, 2005); Nancy, Déconstruction du christianisme, vol. 2, L'adoration (Paris: Galilée, 2010).

15 Jean-Luc Nancy, La création du monde, ou la mondialisation (Paris: Galilée, 2002); Nancy, Creation of the World, or Globalization, trans. François Raffoul and David Pettigrew (Albany: State University of New York Press, 2007); Nancy, Au fond des images (Paris: Galilée, 2003); Nancy, The Ground of the Image, trans. Jeff Fort (New York: Fordham University Press, 2008); Nancy, Noli me tangere: Essai sur la levée du corps (Paris: Bayard, 2003); Nancy, Noli me tangere: On the Raising of the Body, trans. Sarah Clift, Pascale-Anne Brault, and Michael Naas (New York: Fordham University Press, 2008); Nancy, Corpus II: Writings on Sexuality, trans. Anne O’Byrne (New York: Fordham University Press, 2013).

${ }^{16}$ See Nancy, Dis-Enclosure, 1. 
Christian. ${ }^{17}$ He wants to think without any regard for God, and claims to speak of Christianity out of necessity rather than by choice. ${ }^{18}$ Because of Christianity's pervasive influence in the West and, consequently, throughout the world, Nancy feels compelled to examine and to critique it. He remarks, "Our time is thus one in which it is urgent that the West-or what remains of it-analyze its own becoming, turn back to examine its provenance and trajectory, and question itself concerning the process of decomposition of sense to which it has given rise." 19 Thus Nancy sets the agenda for his deconstruction: in response to a collapse of "sense," he rereads the history of the West. This necessitates rereading Christianity.

In a way markedly influenced by Maurice Merleau-Ponty (1908-61), ${ }^{20}$ Nancy contends that philosophy must begin with, proceed as, and end in a thinking of body, of flesh and blood bodies in the world, together, struggling for survival and occasionally enjoying themselves. ${ }^{21}$ His rereading of the history of the West centers on the body. He contests the metaphysical tradition of thinking the body, up to and including Jean-Paul Sartre, because it is utterly unable to treat bare, bodily existence. ${ }^{22}$ Metaphysical thinking, which strongly inflects Christianity (and vice versa), obscures the body precisely as it claims to discuss it. ${ }^{23}$

Nancy argues that a deconstruction of Christianity must proceed in two gestures, and both must contest this obfuscation of the body. La déclosion

17 Nancy, Adoration, 32: “There is not even 'atheism'; 'atheist' is not enough! It is the positing of the principle that must be emptied. It is not enough to say that God takes leave, withdraws, or is incommensurable. It is even less a question of placing another principle on this throne-Mankind, Reason, Society. It is a question of coming to grips with this: the world rests on nothing-and this in its keenest sense."

18 Nancy, Adoration, 22: "Why speak of Christianity? In truth, I'd like to speak of it as little as possible. I'd like to move toward an effacement of this name and of the whole corpus of references that follows it-a corpus that is already mostly effaced or has lost its vitality."

19 Nancy, Dis-Enclosure, 30.

${ }^{20}$ Of particular importance for Nancy is Merleau-Ponty's later work on the flesh. See Maurice Merleau-Ponty, The Visible and the Invisible, Followed by Working Notes, trans. Alphonso Lingis (Evanston, IL: Northwestern University Press, 1968).

21 This argument is a staple of Nancy's thought perhaps from the beginning, but he starts pursuing it in earnest especially in Le sens du monde (Paris: Galilée, 1993); Nancy, The Sense of the World, trans. Jeffrey S. Librett (Minneapolis: University of Minnesota Press, 1997).

22 Nancy, Corpus, 15: “There's no 'death,' taken as an essence to which we've been consigned: there's the body, the mortal spacing of the body, registering the fact that existence has no essence (not even 'death'), but only ex-ists." The claim that existence has no essence is the advance beyond Sartre.

23 See Nancy, Corpus, 65-67. 
is the opening of reason so it might incorporate the body. L'adoration is a practical rapport with the body that follows from la déclosion. Cultivating la déclosion and l'adoration involves jettisoning, among other things, the Christian God from thought and life, or recognizing that God really was never there in the first place. But so too does it involve understanding the space that "God" occupies, and the ethos that "God" convokes.

Nancy contends that in today's world, we are living out a disastrous scenario that the West was bound to bring about, and to which Christianity has helped to give birth. The injustice of today's world, the pain, the suffering, the commodification, overworking, mangling, crushing, and mass burying of bodies, follow quite logically from the Western-Christian mode of reason that has shaped the world-system. ${ }^{24}$ This form of reason is the Western, demonstrably Christian logic of "incarnation," which takes interest in bodies that "spirit has made or engendered," or in "the body as revealed mystery." ${ }_{25}$ Such logic forgets to consider bodies irrespective of their signification, or of their having been engendered by spirit, or of their appearing without mystery's radiance. From this set of interests and noninterests follows much of the misery of today's world, exacerbated by the excesses of globalized capitalism. ${ }^{26}$

These ideas stem from Nancy's earlier thinking of "sense," which for him denotes the meaning of the world without reference to something outside the world. ${ }^{27}$ As I have already observed, when Nancy writes "sense" he has in mind the bodily senses and their experience, the "sense [that] precedes all appropriation [by signification] or succeeds on and exceeds it." ${ }^{28}$ For Nancy, especially in the wake of globalization, which has attempted to signify everything (under the rubric of capital), all that remains is this experience of sense. Transcendence, as it used to be denoted in Western metaphysics and Christian theology, no longer holds sway. If one feels compelled to speak of transcendence in this world, one should instead speak of

${ }^{24}$ One might remark that Nancy is merely borrowing here from Karl Marx. This is, in part, right, but just as Marx accused Ludwig Feuerbach of being too residually theological in his rejection of Christianity, so does Nancy accuse Marx of the same transgression. Marx believed in teleology. Nancy does not. Nancy proposes, in lieu of a telos that will never come, a struggle for a justice that may never come, but for which nevertheless one must struggle. See Nancy, Creation of the World, 38-39, 45, 109-12.

25 Nancy, Corpus, 87.

${ }^{26}$ Ibid., 111. For my recent discussion of Nancy's alignment of Christianity and capitalism, see Peter Joseph Fritz, "Capitalism—or Christianity: Jean-Luc Nancy on Creation and Incarnation," Political Theology 15 (2014): 421-37.

${ }^{27}$ Cf. Peter Gratton and Marie-Eve Morin, introduction to Jean-Luc Nancy and Plural Thinking, 1-10, at 3.

${ }^{28}$ Nancy, Sense of the World, 11. 
"transimmanence." With this word Nancy means a kind of immanence "that does not go outside itself in transcending." ${ }^{29}$ Sense's transcendence, or transimmanence, is this-worldly, not moving toward another world and certainly not relying on another world for its meaning, significance, or signification. Also, sense's transimmanence is never fixed and never static because it is never complete.

In Le sens du monde (1993), his chief work on the topic of sense, Nancy sets forth a program for his deconstruction of Christianity: "That which we have to think henceforth under the title of sense can consist only in the abandonment of Christian sense or in an abandoned sense." 30 The deconstruction of Christianity predicates itself on the conviction that Christian meaning exists today in a state of abandonment-not only has the West been "secularized," but Christianity's capacity for making sense has exhausted itself. It has exhausted itself because Christianity predicates itself upon the need for sense's completion. In a world where sense's completion proves impossible, so too does Christian belief prove impossible. This is what Nietzsche meant by "the death of God." Nancy proposes a kind of thinking and a way of life that attend to the sense that Christianity has tended to forget, as it consistently drops real bodies in favor of "the spiritual life of the sign." ${ }^{31}$ This thinking is la déclosion; this way of life is "adoration."

\section{Angelic Logic: Hoc est corpus meum and Noli me tangere}

Nancy opens La déclosion with a brief statement about the project's chief question. It is a question of "opening mere reason up to the limitlessness of its truth," of showing what remains once reason has accounted for everything, and of "opening up the earth-dark, hard, and lost in space." ${ }^{2}$ He aims to dis-close reason, to open what seemed foreclosed, or to discover reason's capacity for dis-closing itself, even though its history has been one largely of closure. This part discusses how Nancy identifies the "angelic logic" that dominates Western reason, and attempts to dis-close a logic that lies latent and forgotten within Western reason.

29 Jean-Luc Nancy, The Muses, trans. Peggy Kamuf (Stanford, CA: Stanford University Press, 1996), 35. For a theological appropriation of Nancy's transimmanence, see Mark Lewis Taylor, The Theological and the Political: On the Weight of the World (Minneapolis: Fortress Press, 2011), esp. chaps. 3-5.

${ }^{30}$ Nancy, Sense of the World, 55.

${ }^{31}$ Nancy, Corpus, 83.

${ }^{32}$ Nancy, Dis-Enclosure, 1. 
Nancy sees as emblematic of the entire Christian worldview the phrase "being in the world without being of the world." 33 This worldview is constitutive not only of Christianity on Nancy's reading, but also of the West more generally. "In the world, not of the world" becomes a governing logic, which Nancy calls "angelic logic." 34 This is another way of referring to the logic of incarnation. Nancy refers to Gabriel's message in the Gospel of Luke (Luke 1:26-38), which announces that God's son will come down from heaven and take on a body. Nancy deems it ironic-and telling-that a figure without a body announces the incarnation. Western-Christian logic figures bodies as signs that do not have their own sense, but are given sense from "without" - from outside the world, or from a way of being outside the body. Angelic logic becomes law for the West. ${ }^{35}$ Consequently, wherever Western logic takes hold, bodies tend to be oversignified (e.g., individual bodies are treated baldly as "laborers," are commodified in sex trafficking, or are viewed as "collateral damage" in war, or as potential consumers in "emerging markets"). Angelic logic is a logic of occupation. The space of the body is occupied "by a space initially not connatural to it," thereby forcing the body to "represent" the occupier. ${ }^{36}$ Bodies are robbed of any autochthonous meaning or freedom.

I noted above that Nancy commences his deconstruction of Christianity with the words of eucharistic consecration from the Catholic Mass: Hoc est enim corpus meum (This is my body). ${ }^{37} \mathrm{He}$ states that this phrase defines Western culture, delineating its obsession:

The anxiety, the desire to see, touch, and eat the body of God, to be that body and be nothing but that, forms the principle of Western (un)reason ([dé]raison). That's why the body, bodily, never happens, least of all when it's named and convoked. For us, the body is always sacrificed: eucharist. ${ }^{38}$

33 Nancy, Adoration, 23 (emphasis in the original).

${ }^{34}$ Nancy, Corpus, 67.

35 Ibid.: "Through and through, angelic logic and the whole corpus of philosophical bodies are subjected to the signifying law, in such a way that signification (or representation) gives sense to the body, making it the sign of sense. All bodies are signs, just as all signs are (signifying) bodies."

${ }^{36}$ Nancy, Dis-Enclosure, 81.

37 Nancy, Corpus, 3.

${ }^{38}$ Ibid., 5 (emphasis in the original). For Nancy's earlier thinking on sacrifice, religion, and the body, see Nancy, "The Sublime Offering," in Jean-François Courtine et al., Of the Sublime: Presence in Question, trans. Jeffrey S. Librett (Albany: State University of New York Press, 1993), 25-54. 
The Eucharist commemorates the incarnation, which is announced by a bodiless angel. If the incarnation is announced as God's assumption of a body, Nancy reasons, the Eucharist is emblematic of an infiltration of the body from the outside. Western philosophy, Christian theology, and Western-Christian culture are obsessed with such infiltration. The greatest instantiation of bodiliness, the "body of God," consists in an occupation of bodiliness-with all the implications of a hostile takeover. Thus Western meaning-making and treatment of bodies are founded on this model of a hostile takeover, or put only slightly more positively, a comprehensive forgetting of bodies in favor of a meaning outside sense. Nancy sums up his charges against angelic-incarnational logic and its systemic forgetting of bodies: "The signifying body...incarnates one thing only: the absolute contradiction of not being able to be a body without being the body of a spirit, which disembodies it." 39 This misfire of Western reason shapes the Western-Christian ethos, making it an ethos of disembodiment.

But Western reason could operate differently. If its pathology corresponds to its attachment to Hoc est corpus meum, Nancy suggests that a different, correlative, and salutary form of reason abides within Christianity that corresponds to another Christian phrase: Noli me tangere. This is the phrase uttered by Jesus to Mary Magdalene in John 20:17, commonly translated as "Do not hold on to me" (NRSV) or "stop holding on to me" (NAB). Nancy seizes upon this phrase as a piece of tradition that tends to be forgotten by Christian reason and life, but which has lived on in Christian painting. He devotes a substantial essay to this topic. ${ }^{40}$ It so attracts him that it becomes a strange counterpart to the Eucharist, where the body of God is touched (and not only that-consumed). Here we have Jesus' injunction for Mary not to touch him. Nancy recognizes in this juxtaposition of Hoc est corpus meum and Noli me tangere a paradox worth considering. Ian James puts it best when he writes, "Every hoc est enim corpus meum is haunted by a noli me tangere." 41 Nancy hints that thinking this haunting paradox will prove decisive for deconstructing Christianity.

Nancy points out that nowhere in the gospels other than John 20:17 does Jesus refuse to let others touch him. ${ }^{42}$ Nancy also enjoins his reader to notice that the body that Jesus prohibits Mary from touching is his risen body, also called his glorified body. A glorified body is the ideal for the angelic logic of Christianity and the West, since a glorified body is a body whose presence

\footnotetext{
39 Nancy, Corpus, 69 (emphasis in the original).

40 Nancy, Noli me tangere, 3-54.

41 Ian James, "Incarnation and Infinity," in Re-treating Religion, 243-60, at 254.

42 Nancy, Noli me tangere, 14.
} 
is fixed, whose significance is secure. ${ }^{43}$ But Jesus tells Mary not to touch his glorified body, not to become attached to it and to hold it back. Nancy finds in this scene a "nonreligious meaning" of resurrection that could undo the Christian-Western-ontotheological fixation on, and of, the glorified body: "What for religion is the renewal of a presence that bears the phantasmagoric assurance of immortality is revealed here to be nothing other than the departing into which presence actually withdraws, bearing its sense in accordance with this parting." 44 Noli me tangere pertains not just to a fleeting encounter between the risen Christ and Mary Magdalene, but it teaches how presence works. Presence is not fixed. Its analogue is not the spiritual guarantee of a glorified body. Instead, presence exists in the movement of sense, which comes and passes away, and ought not to be held back. Hence Nancy's translation of Noli me tangere not as "Do not touch me," but, noticing that noli participates in the Latin pairing nolo-volo, as "Do not wish to touch me." 45 The key to opposing angelic logic consists in not wanting to hold onto the body, not wanting to fix its presence, not wanting to signify it, not wanting to disembody it.

Within the phrase Noli me tangere, thus within Christianity itself, Nancy detects resources for accessing and developing a different logic, which Ian James calls a logic of presentation rather than representation. ${ }^{46}$ Unlike angelic logic, where spirit re-presents itself in flesh, the logic of Noli me tangere presents flesh and bodies as they make sense, in their coming and going. Thinking the paradox of Hoc est corpus meum and Noli me tangere can lead to a dis-closure of Western reason, to the remembering of forgotten (and oversignified and brutalized) bodies. This is the upshot of la déclosion.

\section{Relation and Saluting Bodies}

Following upon the dis-closure of Western-Christian reason in Nancy's deconstruction of Christianity is his account of adoration, a praxis consonant with dis-closed reason, and appropriate to the current world-situation. The worldwide expansion of Western reason (through capitalist globalization) has ended. Western reason has been exposed as limited and contingent. Because of this, the "entire order" of signification has been "put back into play by...'sense.'"47 Adoration is suited to this new play of sense. It consists

43 See Nancy, Corpus, 61-65, on "glorious" bodies.

${ }^{44}$ Nancy, Noli me tangere, 15.

${ }^{45}$ Ibid., 37.

${ }^{46}$ James, "Incarnation and Infinity," 253.

47 Nancy, Adoration, 7. 
in thinking and feeling according to the opening, the interruption, and the overflowing of sense. ${ }^{48}$ For Nancy, adoration means addressing oneself to the "infinite," not a world beyond this one, but the uncanny ability of beings to self-transcend in the midst of this world (transimmanence). ${ }^{49}$ Adoration is a way of living out Noli me tangere: "Adoration consists in holding onto the nothing," in not wanting to hold onto fixed significance. ${ }^{50}$ Nancy is clearest when he relates adoration to art, or points out that art is a form of adoration. He calls "art" the various "ways of fashioning and exchanging sense outside of signification." ${ }_{51}$

Adoration is a way of relating: of humans relating to one another and to other beings in the world, of recognizing "world" as a series of relations. The term "relation" proves essential to Nancy's genealogy of the Western ethos, which is part and parcel of his account of adoration. "Relation" is distinguished from "observance." ${ }^{2}$ The former term Nancy evaluates positively, and the latter, negatively. This distinction and evaluation materialize during Nancy's description of Christianity's rise alongside the Roman Empire's fall-the opening of one world as another ended. Nancy observes, "This world had been... a world of observance-that is to say, of what defines, in the most proper way, religio, the scrupulous observance (of rules, of rituals) of which Rome provided, in that word, the most precise image."53 The Romans used enforced observance as a tool of domination. With the words "force and riches" Nancy summarizes the Roman ethos. ${ }^{54}$ This ethos is precisely what early Christianity opposed, with its commitment to nonviolence and its pitiless condemnation of riches. ${ }^{55}$ The Christian commandment to love overturns Roman force and riches. Christian love "declares the impossible itself," namely, an unforeseeable cultural mutation by which everyone is assigned an "incommensurable price" - everybody is regarded as of inestimable worth and dignity, irrespective of wealth or hierarchy. ${ }^{56}$ "Relation," then, signifies a link between people shaped by dignity and shared value, rather than rules, regulations, rituals, and rigid order.

But from very early on, Christianity deviates from the impulse by which it originally broke from the Roman order. This is not to say that Nancy, à la

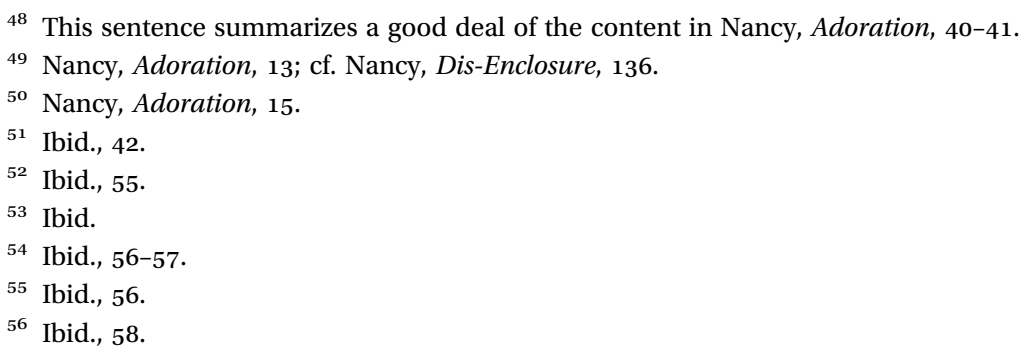


liberal Protestantism, conceives of a "good primitive" Christianity from which subsequent Christianity falls. He explicitly rules out a "Rousseauism of Christianity." 57 Instead, Nancy notes that Christianity's ethos includes not just "relation," but also "observance." When Christianity becomes a religion, it chooses "observance" over "relation." ${ }^{58}$ Nancy gives three examples of overarching ways that Christianity maintained itself as a religion: Orthodox, Roman Catholic, and "puritan." The second, central one seems most important, since Nancy devotes the most words to it: "the most initiatory or magical aspects of the Roman Catholic tradition (sacraments, ecclesiastical authority)." 59 With the "observation" of the sacraments and hierarchical authority, the Roman Catholic Church promises and calculates "another life, replacing and remunerating this one."60 It replaces the Roman Empire's physical domination of bodies with a spiritual domination of bodies.

The observance-relation pairing relates to another: "addiction" and "adoration." ${ }^{61}$ Both terms imply a relationship to a presence that interrupts one's current situation ("here") to allow access to a different situation ("elsewhere"). By "addiction" Nancy means "a relationship to a tangible, appropriable presence," the most exemplary manifestation of which is "hallucination."62 "Adoration" is altogether different; it involves a relationship "that must be known and affirmed as essentially 'elsewhere,' with the effect of opening the "here.'"63 Instead of presence, adoration indicates an opening that breaks out of the "here." With "adoration," there is no arrival of an otherworldly "elsewhere" because there is no such thing. "Here" is the only reality. The good news is that "here" has the capacity to open itself and to transcend itself. Should anything like Christianity survive, it would have to survive by affirming the openness of the world, without idols, myths, or religion, in the sense of "the observance of behaviors and representations that respond to a claim for sense as a claim for assurance, destination, accomplishment." 64 It must break its addiction to observance, and learn to adore relation.

How can Christianity do this? Nancy advises that Christianity reassess its central symbols: trinity, incarnation, and resurrection. ${ }^{65}$ Nancy treats these as

57 Nancy, Dis-Enclosure, 150.

58 Nancy, Adoration, 26: "In truth, Christianity unceasingly reforged the sacred link and religious observance, because its destiny as a religion depended on them."

59 Nancy, Adoration, 27.

60 Ibid.

61 Ibid., 8.

62 Ibid.

63 Ibid., 9.

64 Ibid., 39.

65 Ibid., 49. 
mysteries, but in a modified sense: a mystery is that which is so patent that onlookers tend to miss it. Or more negatively, people find the obviousness of mystery insufficient or unpalatable, so they construct narratives, accounts, and beliefs to complicate it, thus covering it over.

Nancy's understanding of the trinity is surprisingly conventional, so we can forgo comment. His treatment of incarnation and resurrection heavily revises these mysteries based on the idea of mystery as obviousness: "Incarnation and resurrection...say nothing other than this: the task of making sense falls to us humans, mortals, who have no gods or nature, who are technicians engaged in the indefinite production of 'our' world."66 Nancy recasts Christianity as a grand statement of the obvious: humans live in the world as flesh (incarnation) that self-transcends by relating to other flesh (resurrection). ${ }^{67}$

Nancy's revision of Christianity trades on a protracted exchange between him and Derrida. ${ }^{68}$ Playing on the word salut, which carries connotations of greeting and salvation, Nancy projects the final moment of Christianity's selfdeconstruction, the last gesture that the Christian mysteries will offer to the world: "to salute another life in the midst of this one."69 The inertia of the central Christian mysteries leads to the clear conclusion that body is all there is. Any "outside," any "not of the world," "traverses the body." Nancy proclaims, "Our bodies are...entirely, in their turn, openings of the world, and so are other open bodies, those of animals and plants. They can all salute."70 The "salute" of bodies bids adieu to mystery as a matter of observance, to religion as worship of the otherworldly, to spirit's overtaking of body. "Salute" is another name for "adoration." Salute puts into practice an evaluation of the world different from the one enshrined in Western reason and Christian theology. The salute addresses itself to nothing; it has no object, directs itself toward no presence. The salute keeps sense open.

66 Ibid., 52.

67 Ibid., 52-53.

68 On this exchange, see Kas Saghafi, Apparitions-of Derrida's Other (New York: Fordham University Press, 2010), 129-46; and Steven Shakespeare, "The Word Became Machine: Derrida's Technology of Incarnation," Derrida Today 6, no. 1 (2013): 36-57. The main source on Derrida's side is Jacques Derrida, On Touching-Jean-Luc Nancy, trans. Christine Irizarry (Stanford, CA: Stanford University Press, 2005). This English translation of Derrida's Le toucher (2000) includes a postmortem open letter from Nancy to Derrida; see Jean-Luc Nancy, "Salut to you, salut to the blind we become," in Derrida, On Touching, 313-14. While this exchange is interesting in itself and does relate to what I am working on in this article, I shall not discuss it any further.

69 Nancy, Adoration, 28.

7o Ibid. 


\section{Rahner's Theology of Materiality vis-à-vis Déclosion}

Nancy's deconstruction of Christianity shows two things at once: how Christianity forgets bodies yet bears its own resources for remembering them, or how Christianity forecloses sense while always holding the possibility of reopening it. Nancy contends that Christianity must be allowed to go the way of its own self-exhaustion. But if Christianity indeed bears the promises discovered through Nancy's deconstruction, we must ask why, in the final analysis, Christianity must be abandoned.

The next two sections, which correspond to the two movements of Nancy's deconstruction of Christianity, explore the possibility that Christianity might be maintained while keeping sense open in a way comparable to how Nancy would have it. Karl Rahner will be our guide. We shall find that Rahner's critical interventions with respect to conventional theology and everyday Christian belief and practice bear interesting resonances with Nancy's recent writings. Like Nancy, Rahner demands that contemporary Christians reassess their estimations of bodies. In doing so, they may find that the Christian ethos is far broader-allows for greater sharing of sense-than they tend to recognize. A dialogue with the atheist philosopher highlights the challenge of Rahner's theology for Christian belief and practice, but also (unlike Nancy) his constructive loyalty toward them, a kind of loyalty I would recommend.

Rahner repeatedly insists in numerous writings that Christianity holds a stake in materiality as itself real, not evanescent, imaginary, or simply a sign of some other reality that stands above or over against it.71 "The Unity of Spirit and Matter in the Christian Understanding of Faith" (1963) presents the single most comprehensive Rahnerian defense of the essential unity in plurality of spirit and matter. Rahner mounts this defense in response to a "worldwide materialism which disputes the foundation of the Christian faith." ${ }^{72}$ Rahner's defense is twofold: (1) he collates data from dogmatic and scriptural traditions regarding the unity of spirit and matter, and (2) he reflects systematically on these data to clarify the Christian position on spirit and matter's

${ }^{71}$ Among these are some of Rahner's most familiar writings, such as "The Theology of the Symbol," in More Recent Writings, vol. 4 of Theological Investigations, trans. Kevin Smyth (Baltimore: Helicon Press, 1966), 221-52; and Rahner, The Church and Sacraments, trans. W. J. O'Hara (New York: Herder and Herder, 1963). For a one-volume collection of these familiar works and many important lesser-known ones, consult Rahner, Leiblichkeit der Gnade. This editor-selected title of volume 18 of the Sämtliche Werke, which can be translated as Corporeality of Grace, cries out for a Rahner-Nancy dialogue such as I am prosecuting here.

${ }^{72}$ Rahner, "Unity," 153. 
relation. I shall hone in on just three facets of this defense: Rahner's initial statement of Christianity's opposition to denigration of matter, his adducing of angels as a counterintuitive yet helpful example of Christianity's belief in matter and spirit's common history, and his account of intraworldly selfbecoming. These three facets should illustrate Rahner's recasting of Christian theological reason, in a manner analogous to Nancy's la déclosion.

The Christian dogma of creation explicitly contests dualistic and gnostic interpretations of matter. ${ }^{73}$ For the dogmatic tradition, matter is good (Gen 1:31). By contrast, the philosophical tradition has continually opposed this dogma:

Again and again, matter has been experienced as something dark, antidivine, obscure or chaotic; again and again, it has been seen as something which stands in contradiction and bitter combat against the spirit understood as the true image and representative of God in the world, a combat which constitutes the history of nature and of the world. Again and again, Christianity has protested against these conceptions as incorrect and hasty interpretations of human experience and, even though not everything in this falsely interpreted human experience was wrong, has condemned them as error and heresy. ${ }^{74}$

It would stand to reason that if matter were "dark, anti-divine, obscure or chaotic," it would stand in need of supplementation (or infiltration and occupation) by spirit. But as Rahner reads the Christian tradition, it does not see matter as any of these things. The relationship between spirit and matter, then, must not be one of supplementation, infiltration, or occupation. Nancy may be right that in fact Christianity has more nearly resembled the kind of denigration of matter that Rahner deems erroneous or heretical. But we must recall that Rahner prompts Christians to remember forgotten truths about the tradition. This could include Christianity's fundamental appreciation for the body, which as Rahner sees it, has been affirmed "again and again" throughout history.

Rahner illustrates his point in what might seem a digression. He writes almost two pages about angels. Since Nancy derides the "angelic logic" of Christianity, the theme of the angel proves rather pertinent. And it is clearly important to Rahner, as he refers to angels multiple times later in the article. ${ }^{75}$

Rahner acknowledges that in much of the Christian tradition angels "are characterized in a platonic formula as "pure spirits." 76 This leads to the

\footnotetext{
73 Ibid., 156.

74 Ibid., 155-56.

75 Ibid., 166, 169, 173.

76 Ibid., 158.
} 
common perception "that there is a created kingdom of finite spirits which carries on its own history quite independently from the material world and its history; and that this shows that spirit and matter are only very partially connected with one another even within the realm of created reality." ${ }^{77}$ This "average, ordinary understanding of faith" seems to be what Nancy is critiquing, and which he deems to be constitutive of Western reason, Christian or otherwise. Rahner continues, further corroborating Nancy's perception of Christianity: "On this basis, it is then almost inevitable, psychologically speaking, that one ends up with the conception of the world as the merely accidental and ultimately superfluous scene of an itself again also matter-less history." ${ }^{78}$ Then Rahner changes course: the "conception of the angels current among ordinary people" is too "fairy-tale" to be true. The matterless understanding of angels, while it may have occurred at various points in Christian history, is not constitutive of Christian belief or reason.

Rahner makes his case for this claim with reference to the Bible. There is ample scriptural evidence that the history of the angels and the history of the world "are at least interlaced in many respects." 79 Material creation and the angels share a goal in the kingdom of God, angels receive the same grace as material creatures, angels do work in the world, and, in Ephesians and Colossians, the angels function as cosmic powers that make a difference for the material world. Finally, the angels, as is stated plainly in Hebrews, relate inexorably to the salvation completed in Christ, which has an undeniable relation to material creation (Heb 1:4-2:2). Rahner contends that the "doctrine of the angels understood as 'pure spirits,' however materially correct, unjustifiably lends too much support to a platonic and nonChristian removal of the created spirit from this world." ${ }^{\text {8o }}$ Rahner concludes that angels cannot be used as evidence that Christianity holds to some belief in the disunity of spirit and matter. In fact, angels corroborate Christian belief in their historical unity. ${ }^{81}$ Christianity rightly understood upholds no "angelic logic." One could say, though, that Christianity utilizes a different, true angelic logic, where spiritual creation cooperates nondualistically with material creation.

77 Ibid.

${ }^{78}$ Ibid.

79 Ibid., 159.

80 Ibid.

${ }^{81}$ Rahner makes apposite comments about angels' relation to the material world in The Theology of Death, a book that has been underappreciated as a speculative work. See Rahner, The Theology of Death, trans. W. J. O'Hara (New York: Herder and Herder, 1961), 23, 52-53. 
While this intervention regarding angels generates an important rejoinder to Nancy, perhaps a more interesting one from Rahner's "Unity" article appears in its final pages. Here Rahner condenses thoughts that he published elsewhere on the question of human evolution. ${ }^{82}$ The discussion begins when Rahner states that matter is "in a sense 'frozen' spirit." 83 At least one of Rahner's Catholic critics deems this phrase disturbing. ${ }^{84}$ But for our purposes it offers a rich opportunity for dialogue with Nancy. Depending on how one interprets this phrase, it could either vex or please him. This could be a prime example of Christian disembodying of body, thus canceling out Rahner's prior efforts, or it could be an example of understanding spirit in a way similar to Nancy's Noli me tangere. Rahner presents this suggestive phrase to drive home the point that, on a truly Christian view, matter and spirit cannot be regarded "as alien to one another." ${ }^{85} \mathrm{He}$ complements his "spiritual" characterization of matter with a "material" depiction of spirit: "The spirit must only be conceived in the sense that the finite spirit searches for and finds itself through the fulfillment of the material itself." ${ }^{86}$ Nancy and others might believe they detect here the typical structure of spirit's exploitation of matter for its own gain. But the phrase "fulfillment of the material" must be understood exactly as it reads: matter reaches fulfillment in cooperation with spirit, without undue "glorification."

Whether one has in mind the germination of a plant in a few days' time or the evolution of species over millennia, matter becomes something else. "There is becoming," Rahner observes, "and this becoming is ultimately not just the merely spatially, temporally, and quantitatively transformed combination of basic elements which remain statically the same, but is the becoming of something really new which has an intramundane origin and yet is not

82 Karl Rahner and Paul Overhage, Das Problem der Hominisation (Freiburg: Herder, 1961); Rahner and Overhage, Hominisation, trans. W. J. O'Hara (New York: Herder and Herder, 1965).

83 Rahner, "Unity," 168; see 177.

84 Patrick Burke, for example, expresses reservations regarding this phrase, but he never specifies them. It is telling that he promises to return later in his book to the idea of "frozen spirit" so he might critique the incipient "philosophical monism" he detects in it. Telling, because if one knows Rahner, one knows that his thought differs widely from philosophical monism, be it ancient (Plato) or modern (Spinoza). Thus, it is likely that no adequate critique could have been constructed. Instead, Rahner's thinking on things like matter as "frozen spirit" avoids the specter of monism while, perhaps paradoxically, aspiring to a certain nondualism-or, as Rahner would call it, Christianity. See Burke, Reinterpreting Rahner: A Critical Study of His Major Themes (New York: Fordham University Press, 2002), 102, 110.

85 Rahner, "Unity," 170.

86 Ibid., 169. 
simply the same as that from which it originates." ${ }^{87}$ This becoming is selfsurpassing, transcendence. Lest it seem like the word "transcendence" implies matter's destruction or fixation, Rahner clarifies that this self-surpassing really is self-surpassing. The "self" of matter abides. Even if matter's transcendence is figured by Thomistic philosophy and theology as self-surpassing into spirit, this need not imply that matter is unduly "signfied." When matter becomes more spiritual, "this does not mean the positing of an absolutely separate and alien existent in the sense of a simple generatio aequivoca." ${ }^{88}$ Instead, matter works as limitation toward its unlimitation, or spirit. ${ }^{89}$ In this way Rahner's "frozen spirit" inverts a reader's initial expectation in a way analogous to Nancy's creative torsion of Noli me tangere, only that Rahner's creative turn is toward the Christian tradition rather than away from it. If the philosopher's worries about Christianity are not allayed, nevertheless a benefit comes to Christians from his deconstruction of Christianity: Christians can appreciate anew the value of materiality, and the reason that they apply to materiality can be dis-closed.

\section{Rahner's “Copernican Turn” vis-à-vis Adoration}

It remains to address Nancy's anxiety with respect to the ethos shaped by Western-Christian, thus eucharistic, signification, which precipitates his proposal of adoration as an alternative. "Considerations on the Personal Realization of the Sacramental Event" (1970) is a perfect Rahnerian resource toward this end, since it contains some of his most fecund ideas on the Eucharist, and the sacramental ethos more generally. Most remarkably, Rahner develops his famous idea of a "Copernican turn" (kopernikanischen Wende) in sacramental theology. ${ }^{90}$ The "turn" concerns a shift from one theological model for understanding the sacraments to another, and consequently to another way of leading sacramental life.

The old, neo-Scholastic model, which corresponds uncannily to the type of Western thinking that Nancy critiques, conceptualizes the sacraments as occurring over against the world. Rahner's description of the old model is worth quoting at length:

The Christian experiences himself living in a profane world. He knows he is in this world under God's commands, which are difficult to fulfill, he knows

\footnotetext{
${ }^{87}$ Ibid., 174.

88 Ibid., 176.

${ }^{89}$ Cf. Rahner, "Unity," 169.

90 Rahner, "Personalen Vollzug," 458.
} 
himself as called by God and sent on a path that leads through the gate of death out of this life into God's eternity. In order to have a connection now with God, his proper future and the lawgiver over his life, he retires from out this profane world into a sacred precinct, a "fanum," a "templum," where for the first time...an actual encounter with God is possible, where this God meets him not only as the morally demanding One, but as the sanctifying, grace-giving, power-bestowing One....Here in the sacrament (otherwise how else?) is one near and united to the Lord, here one has left the profane world behind, here and, in fact, here alone occurs that which makes life meaningful and "religious." 91

The old model rests on several principles: (1) a sharp distinction between the sacred and the profane, (2) an equally sharp distinction between time and eternity, (3) a decided preference for the sacred and eternity over their counterparts, and, consequently, (4) a construal of the sacraments as means of escape from the profane and temporal world to the sacred and eternity. Rahner points out that this old model is threatened in the contemporary world, since it invites secular suspicion of "ritualism"-or what Nancy would call "observance." 92

Even more important, though, is a "developing recognition of the distinction between a genuine, original living out (Vollzug) of existence and the conceptual, representational models for reflecting on existence."93 It is hard to square, for instance, the old model's conceptualization of the sacraments with the lived experience of freedom, which frequently does not seem to reach its pinnacle in the sacraments' ritual celebration. ${ }^{94}$ How can the Eucharist in its actual practice seem so mundane, when theologians insist that while celebrating it worshipers surpass the world? The old model offers no adequate answers.

Rahner's Copernican turn moves toward a new model, "based in the simple dogmatic fact that what we call sanctifying grace and divine life is given everywhere where one does not close himself from the saving God through an actual, culpable 'No.'"95 This new model answers the modern objection to the old model, which gives the impression that "with the sacraments we are dealing with an ideological elevation of a ghastly, profane world, which obscures the truth, but does not really change the world." ${ }^{96}$ In keeping with his rendering of matter and spirit's mutual becoming, Rahner

\footnotetext{
91 Ibid., 459.

92 Ibid.

93 Ibid., 461.

94 Ibid.

95 Ibid., 462.

96 Ibid., 463.
} 
recasts the sacraments as working within the world for the world's own selfsurpassing. The world is limited, for sure, but to portray it as "ghastly" or "profane" has the same consequences as a Platonic denigration of matter. The sacraments, as substantial signs of grace in the world-of the corporeality of grace-unlimit worldly limitations, all the while preserving the world's materiality.

Nancy extols the world when it properly occurs in "relation" as worthy of adoration. Rahner's new model agrees in large measure: "Throughout the length and breadth of this monstrous story of birth and death, full on the one hand of superficiality, stupidity, inadequacy and hatred (which all 'crucify'), and on the other of silent resignation, responsibility all the way to death, in death and in joy, in heights and falls, the proper (eigentliche) liturgy of the world is given." ${ }^{97}$ Rahner echoes avant la lettre Nancy's advocacy of adoration as a respectful address to the world qua world/body. But not only this: Rahner expresses his concern that Catholic liturgies, and one could infer Catholic life more widely, not collapse into "observance."

In an extraordinarily interesting passage, Rahner speaks to the apprehensions of a person who fears that in attending the Eucharist she engages in empty ritualism. He provides two recommendations. First, this person "must appeal to the experience of God and grace in [t]his apparently profane life and say, 'This experience and its object are graspable cultically and ritually.'" The idea of the liturgy of the world could make sense of the eucharistic liturgy for her. Second, if this does not work because a person insists that she has not experienced God or grace, then "inevitably the sacraments will occur to [her] as magical ritualism, and according to Christian teaching [she] should not even receive them." This person would need instruction and mystagogy ${ }^{98}$ These recommendations imply that the collapse into observation is not inevitable, but an unfortunate consequence of one's understanding of the world, of the sacraments as signs, or both.

Rahner has theological responsibilities that Nancy does not. Among them, Rahner must establish his view of the liturgy of the world in conversation with the (at that point) recent proclamation of the Second Vatican Council that the eucharistic liturgy is the culmen et fons ("summit and source," or Gipfel und Quelle) of Catholic life. ${ }^{99}$ Thus he must respond to objections that his idea of

97 Ibid., 465. I translate the polysemic word eigentliche as "proper" to underscore the fact that, for Rahner, the liturgy of the world really does belong to the world, inasmuch as God has created the world with its own capacity for self-transcendence.

98 Rahner, "Personalen Vollzug," 468.

99 Second Vatican Council, Dogmatic Constitution on the Sacred Liturgy (Sacrosanctum Concilium), \$10, in Decrees of the Ecumenical Councils, ed. Norman P. Tanner (Washington, DC: Georgetown University Press, 1990), 2:823. 
the "liturgy of the world" renders the particular liturgy of the Eucharist superfluous or meaningless. ${ }^{100}$ But instead of these responsibilities steering Rahner off track from a meaningful Auseinandersetzung with Nancy, they facilitate the discussion. The Eucharist constitutes the source and summit of Christian life because it relates (to) the whole of each individual Christian life, and of the communal life of the church. Not simply this, but the manifestation of God's grace that occurs in the sacramental sign "is bestowed upon the world as such from its heart and center." ${ }^{101}$ God's grace does not "occupy" materiality. Instead, the recipient of the sacraments, Eucharist or otherwise, "integrates more 'material' in his own history." ${ }^{102}$ So too with the worldfor Rahner's new model "the sacraments are not 'extrinsicist' processes, which impinge upon an unholy world from 'without', but the pro-cesses (Vor-gänge) ... of the grace of the world." ${ }^{103}$ In this way Rahner shows how Christianity achieves in actuality what Nancy's deconstruction of Christianity regards merely as a latent possibility: adoring the world from within.

Surely Christians will need to be convinced of this possibility, and in the face of Nancy's deconstruction of Christianity (and similar calls to abandon Christianity to its own dissolution) they may need encouragement to remain loyal to the Christian faith. But Rahner's account of the personal realization of the sacramental event at the very least prompts Christians to attempt a praxis akin to Nancy's adoration, and to attempt it within Christianity-perhaps as a kind of "elsewhere" within Christianity's "here."

\section{Conclusion: The "Yet Without" and the Body's Singularity}

In brief, theology would need to violate Nancy's thought, to ignore its "nihilistic" tones and to make ostensible appropriations in order to render it pertinent. And what would be chosen would be less interesting, or at least less genuinely Nancean, than what would be overlooked. ${ }^{104}$

Nancy's deconstruction of Christianity is, for certain, more than a critical intervention with respect to the religion called "Christianity." He deconstructs all manner of Western discourses and systems, from ontotheologically

100 Rahner, "Personalen Vollzug," 469.

101 Ibid., 472. A critical reader may note that in the particular sentence I am citing, Rahner considers the individual believer, but his discussion of the church in the prior sentences applies no less to what he says regarding the individual.

102 Rahner, "Personalen Vollzug," 472.

103 Ibid., 474.

104 Hutchens, Jean-Luc Nancy and the Future of Philosophy, 101. 
constituted metaphysics to contemporary capitalism, that fall under the influence (or at least the rubric) of Christianity and that, in their turn, have shaped Christianity. But given this article's aim of introducing Nancy to a theological audience, I have paid particular attention to the ramifications of Nancy's deconstruction of Christianity for specifically Christian thought and practice. The dialogue with Rahner facilitated this theological introduction. Also, the conversation with Nancy illuminated Rahner's theology in a new way, so that his theology might be seen as a guiding light in the world-situation that Nancy describes.

Christopher Watkin argues that Nancy's thought is structured by an impulse that one may call the "yet without": "neither ascetically to renounce theological categories nor parasitically to adopt them wholesale, but rather to seek to occupy them with a radically post-theological thinking." ${ }^{105}$ For Watkin, Nancy's deconstruction of Christianity accomplishes an occupation of theology by post-theology. Adoration in particular "is a gesture of occupation that follows the pattern of the 'yet without.'" 106

Watkin's interpretation of Nancy strikes me as well founded, though he and I differ on how to evaluate Nancy. If we grant to Watkin that Nancy's thought consists in a logic of occupation, this presents an interesting opportunity for critique. How tremendously ironic his thought appears when one recalls that Nancy criticizes Christianity for its own logic of occupation-the "angelic logic" of "incarnation." Watkin does not comment on this irony. This leads one to believe that he, like Nancy, does not notice it. We ought to ask why one logic of occupation is worthy of approval, and the other demands resistance. One can and must sustain Nancy's criticism that, historically, Christianity has been at fault for an improper deployment of reason (or a deployment of improper reason), and by extension for much of the misery of this world. Surely much of the world's misery can be laid at the feet of some "angelic logic" or another, neoliberal capitalism being just the most recent sort. But this fact does not automatically exonerate other logics from all error.

Nor does it necessarily guarantee that forms of reason styled as counter to angelic logic turn out to be completely nonangelic. It is worth asking whether, in the final analysis, Nancy's thinking of the "yet without" is a type of angelic logic, since it demands that Christianity slough off its body (its history, both

${ }^{105}$ Watkin introduces the term "yet without" in passing early in his book, Difficult Atheism (14), and defines it in several ways throughout. The paradigmatic definition is as follows: it "breaks with determinate sense yet without descending into nonsense, it breaks with the infinite horizon yet without closing in on itself in self-identicality" (74). Reference for the block quote: 80.

${ }^{106}$ Watkin, Difficult Atheism, 80. 
positive and negative) in favor of something like "spirit" (a higher form of reason, la déclosion, and its attendant praxis, adoration). ${ }^{107}$ It may in fact be that Christianity's many indiscretions over the centuries have resulted just as much from its intransigent materiality (i.e., that the church is always made up of people) as from angelic logic. Certainly Nancy intends his deconstruction of Christianity as a material operation, but one must ask whether his refusal of Christianity's future is ultimately dematerializing.

For Nancy, Christians have forgotten the body (human, mainly, but he has other this-worldly bodies in mind) because they have fixated on the body of God, and they tend to value this-worldly bodies only inasmuch as they are glorified. Should the body be remembered, the Christian ethos could be reconfigured, but only by an exit from Christianity, and an appropriation of adoration. Our engagement with Rahner calls into question precisely this last move. For Rahner, Christians have forgotten (as we can see in the "older model" of thinking about the sacraments) the positive relationship between spirit and matter that Rahner finds readily discernible in the theological tradition. Reclamation of this forgotten truth is not only possible, but has actually begun to occur in the postconciliar period. Rahner could grant to Nancy that the Christian ethos must consist in something like adoration's positive rapport with the world, but this would happen through a reclamation of Christian memory rather than an exit from Christianity. Rahner's approach would prove more material than Nancy's, since it would involve a continuation of the material life of the church, rather than outright disposal of it. But theologians and other Christians would still owe Nancy some measure of gratitude, since he would have helped Rahner's contribution to snap into focus.

I understand Benjamin Hutchens's forceful contention that a theological "usurping" of Nancy is impossible. Still I see a remaining theological promise in his work. Nancy's notion of symbol, Hutchens submits, proves inimical to a Christian symbolics, because the latter cannot tangle with Nancy's central question "of the singularity of the body as origin of sense itself." ${ }^{108}$ But this question is so close to a central question of Rahner's that I cannot help but end on a positive note. From his philosophical dissertation, Geist in Welt, forward, Rahner argues that human experience begins with the body (sensation), thought occurs only in reference to the body (abstraction), and

${ }^{107}$ It is worth asking, for example, why Nancy begins the book Adoration with the following epigraph from Wittgenstein: "The form of spirit as it awakes is adoration." Nancy, Adoration, 1; cf. 86-87.

${ }^{108}$ Nancy, Adoration, 99. 
comes to its realization through the body (conversion to the phantasm). ${ }^{109}$ And in his long essay "The Logic of Existentiell Recognition in Ignatius Loyola" (1956/58), he explicitly appeals for an ontology more sensitive than ever before to concrete individuality. ${ }^{110}$ In these ways he aims to retrieve lost Christian truths and to show the expansiveness of the Christian ethos. Though he may not be thinking directly of singularity of the body as origin of sense itself, he approaches this thought. He shows theologians a way to be exercised by Nancy's deconstruction of Christianity while leaving the materiality of the Christian tradition intact. ${ }^{111}$

${ }^{109}$ Karl Rahner, Geist in Welt: Zur Metaphysik der endlichen Erkenntnis bei Thomas von Aquin, vol. 2 of Sämtliche Werke, ed. Albert Raffelt (Freiburg: Herder, 1996), 5-300; Rahner, Spirit in the World, trans. William Dych, SJ (New York: Continuum, 1994).

${ }^{110}$ I prefer to cite the German, since the existing English translation presents some serious difficulties. Karl Rahner, "Logik der existentiellen Erkenntnis bei Ignatius von Loyola," in Kirche in den Herausforderungen der Zeit: Studien zur Ekklesiologie und zur kirchlichen Existenz, vol. 10 of Sämtliche Werke, ed. Josef Heislbetz and Albert Raffelt (Freiburg: Herder, 2003), 368-420.

${ }^{111}$ I am grateful to my colleague Matthew Eggemeier for reading and commenting on an earlier draft of this article, and to the three anonymous referees for their generous, detailed suggestions. The final product is far better for all this collaboration. 